\title{
The Power of Petitions: Women and the New Hampshire Provincial Government, I695-I770*
}

\author{
Marcia Schmidt Blaine
}

There are very few sources available to historians which allow us to hear the voices of Anglo-American women. How can we understand what ordinary women believed were their responsibilities to their families and communities and the responsibilities of their government to them? Petitions provide historians with one of the few opportunities to "hear" non-elite women voice their concerns. In provincial New Hampshire, women regularly approached the royal government with individual requests. By viewing the rights associated with petitioning, the procedure involved, and the variety of applications for petition use, female agency in colonial society becomes more apparent. Through petitions, it is possible to understand under what circumstances women turned to the government for assistance, and under what circumstances the government granted their petitions.

The 1699 petition of Deliverance Derry Pittman is a good beginning for analysis. Pittman was the widow of John Derry and the wife of Nathaniel Pitman, and her petition provides a clear picture of a family destroyed by international disputes. The colony of New Hampshire was on the northern edge of English settlement, bounded by Massachusetts to the east and south, the Connecticut River to the west, and New France directly to the north. Because of its location, the colony was intimately involved in the numerous territorial disputes between the empires of England and France. Native Americans took sides in the disputes, with many New England tribes siding with France. Deliverance Pittman and her family were caught in the imperial and intercultural disputes that resulted in King William's War (I689-I697).

[I]n the year 1694 the petitioner's house was burnt by the Indians; and our cattle killed; as also most of our Children; my husband, one child, and the petitioner taken captives; in which captivity my husband dyed; none but your petitioner returned; hoping to enjoy what estate was left by your petitioner's husband.

\footnotetext{
* The author would like to thank Holly Bentley Mitchell, Gregory A. Mark, Frank Mevers, Elaine Forman Crane and, especially, Eliga H. Gould for their comments, advice, and critiques of earlier drafts.
} 
Having managed to bribe her way home, Deliverance learned that her husband's estate was tied up by the men entrusted to protect the estate: Joseph Smith and Jeremiah Burnam, men she felt needed the attention of the government. How could she present the case to the government? Through petition. Smith and Burnam, she protested, have

[...] violently and contrary to law seized; upon your petitioner's cows and estate; the whole amounting to Ninety Pounds, forty five of which are in Lands; all individuals involved [protested that they were doing so] for the good of my children. But in truth the Petitioner knows of noe such children, being now liveing.

As the apparent sole survivor and thus the representative of her first husband's family, Pittman requested that the government force Burnam and Smith to restore the estate (and cows) to her. While the cattle were apparently neglected in the final settlement or delivered without government intervention, the government returned her land to her possession in I70I. Nowhere else is it possible to learn of Pittman's distress. Pittman's new husband presented the petition to the governing body of the colony of New Hampshire on his wife's behalf - but it was her petition. ${ }^{\mathrm{I}}$ Pittman turned to the government when she was unable to gain control of the estate.

Many historians view petitions like Pittman's as excellent examples of provincial women's weak legal power. Given the general expectations regarding women and societal acceptance of patriarchy and coverture, it is easy to assume that women had little autonomy or power in any eighteenthcentury Anglo-American setting. Elaine Forman Crane emphasized "the long-range negative effects" of patriarchy in her detailed work on women in New England seaports. While noting cases of female agency, she concluded that women, especially widows, "were persistently and effectively marginalized in subtle and not-so-subtle ways" due to their sexual and economic vulnerability over the course of the eighteenth century. Using similar language, Cornelia Hughes Dayton concluded that women in the colonial Connecticut legal system were marginalized by the return of traditional patriarchy during the eighteenth century. These and other studies emphasize women's subservient role in eighteenth-century hierarchy. ${ }^{2}$

I. Petitions, I699, New Hampshire Division of Records Management and Archives [hereafter NhAr], Concord, NH; Sybil Noyes, Charles Thornton Libby and Walter Goodwin Davis, Genealogical Dictionary of Maine and New Hampshire (Portland, ME, 1928-1939; repr. Baltimore, MD, I972), p. $55^{8}$. Under the English common law doctrine of coverture, a woman's legal existence ceased with her marriage. Her husband represented the family in the eyes of the law. 2. Elaine Forman Crane, Ebb Tide in New England: Women, Seaports, and Social Change, I630-I800 (Boston, MA, I998), pp. 8, I4I; and Cornelia Hughes Dayton, Women Before the Bar: Gender, Law, and Society in Connecticut, I639-1789 (Chapel Hill, NC, 1995). See also Joan Hoff, Law, Gender E Injustice: A Legal History of US Women (New York, I99I). 
After all, women were subject to their husbands' will as part of the colonial hierarchy; (it was Pittman's husband, not Deliverance Pittman, who presented the petition "on behalf of his wife"). Women had no or very little control over property. Certainly Pittman's wording fits such an analysis when she "Humbly Showeth" her complaint and asks the court to "commiserate the Condition of your Petitioner [...] And your Petitioner Shall pray etc".

But New Hampshire women, like Anglo-American women in other British colonies, had more options available to them than such an interpretation may indicate. While cultural expectations of female passivity, irrationality, and dependency existed, the cultural reality of female loyalty, flexibility, and persistence created a corollary set of expectations for women. Lisa Wilson's work on the life cycles of colonial men has shown the pre-eminence of family to all members of colonial society. Families were interdependent, each part tied by mutual responsibilities and obligations to the rest, where "[e]veryone was not equal, but neither was anyone autonomous". Laurel Thatcher Ulrich also emphasizes the reciprocal nature of familial rights and responsibilities where the husband's decisions, while supreme, were expected to include his wife's opinions and interests. ${ }^{3}$ Women were expected to care for their households and the individuals within them, as well as to take part in their communities as good neighbors. Domestic duties gave women the power and the ability to petition the government to correct perceived errors and to find justice. In the Pittman example, Pittman's new family needed the property Pittman believed belonged to her. The most efficient way to get the land back was to petition the government. In general, women's petitions tended to be personal, rather than political in nature; yet this is a clear instance of the personal being political. Petitioning was an expression of familial leadership available to ordinary women during the colonial era. It gave women who availed themselves of the right a voice with which to inform the government of their needs, opinions, and quarrels.

Petitioning was an "ancient right" in English society, affirmed by the combined governments of the colonies of Massachusetts and New Hampshire in I64I, ostensibly giving subjects license to request from the government the grant of a private act. As part of the Massachusetts' Body of Liberties which codified the colonists' understanding of their basic liberties, the I64I law stated that

[...] [e]very man whether inhabitant or fforreiner, free or not free[,] shall have liberty to come to any publique Court, Councell, [...] and either by speech or writeing to move any lawfull, seasonable, and materiall question, or to present 
any necessary motion, complaint, petition, Bill or information, whereof that meeting hath proper cognizance, so it be done in convenient time, due order, and respective manner.

The I64 I Body of Liberties was developed while England was caught up in its Civil War, a time when laws and rights were in flux. Women in England used the disruption of war to demand the right to petition. "Have we not an equal interest with the men of this Nation in those liberties and securities contained in the Petition of Right, and other good Laws of the Land?" From I64I onward, through all the changes of government and governors, petitioning seems to have been an understood or customary right. While the law did not guarantee the right of petition to female inhabitants of the province, women in New Hampshire clearly believed the right applied to them in a more generic sense, either as subjects of the Crown or as inhabitants of the province of New Hampshire. New Hampshire women availed themselves of the customary right from the beginning of settlement. ${ }^{4}$ Despite their weakened status under the law, women understood they had the right to seek aid from the men in authority. They were assertive enough to exercise the opportunity petitioning provided for civic involvement. They used the customary right and political means of petition to explain a personal need. The women who submitted petitions knew the power of petitioning and the means necessary to complete the process.

Most New Hampshire petitions were presented by a single person or a small group of persons directly to, first, the Governor of the province and his Council and, second, the Assembly. Apparently, the petitioner, or someone representing her (like Pittman's husband), was often, but not always, present. It was understood by everyone involved that all petitions required a governmental hearing and response. 5 It was a way, the most direct way, for subjects to have their wishes heard, discussed, and debated by those in power who then generally rendered a decision within a few

4. For the Body of Liberties, see Albert Stillman Batchellor, Laws of New Hampshire, vol. I (Manchester, NH, 1905), p. 753 [hereafter Laws of NH]. For discussion of female petitioning in England see Crane, Ebb Tide in New England, pp. 236-238, quotation p. 238; and David Underdown, Revel, Riot, and Rebellion: Popular Politics and Culture in England, 1603-1660 (Oxford, 1985).

5. Stephen A. Higginson, "A Short History of the Right to Petition Government for the Redress of Grievances", The Yale Law Journal, 96:142 (1986), pp. I42-I66, I 5;. Gregory A. Mark, "The Vestigial Constitution: The History and Significance of the Right to Petition", Fordham Law Review, 66 (1998), pp. 2153-223I, 2162-2170; "The government [...] felt a socio-political obligation to hear those grievances, to provide a response, and often to act upon the complaints", p. 2 I60. See also Brian Weiser, "Reconstructing the Monarchy: Access to the King in the Reign of Charles II”, (Ph.D., Washington University in St. Louis, I999), for a discussion of the role of petitions in seventeenth-century English society: "To the popular imagination, petitions [...] formed the essential point of contact [...] between rulers and ruled”, p. 8. 
days of receiving the petition. With no clear separation of powers, petitions were used for executive, legislative, and judicial matters. A male petitioner in 1697 stated this understanding plainly, for the petitioner knew of no "other way for the fatherless to come by there [sic] undoubted Right but to come to your Honours for releife". 6 Petitioners trusted the provincial government to listen and give each petition due consideration.

The petitioning process began with writing the petition (or having it written) and submitting the petition and the necessary fees to the secretary of the Governor's Council. Elaine Forman Crane found that submitting a petition to the government of another New England colony, Rhode Island, was an "expensive proposition" where charges reached $£_{4}$ per petition by the mid-eighteenth century, a prohibitive amount for anyone of lesser means. ${ }^{7}$ However, in sharp contrast, the New Hampshire provincial government charged far less. In I71 8 the government's secretary charged from $2 \mathrm{~s} 6 \mathrm{~d}$ to Ios, "according to import" of the petition, and the clerk of the legislature charged an additional $4 \mathrm{~s}$ to read the petition, record the order, and file the records of each action. By 1768 the province had standardized the secretary's fees for petitions to 3 s per entry, regardless of the "import". Such fees would not have hampered women's ability to present their grievances to the colonial government of New Hampshire. ${ }^{8}$

The written petition began with a deferential address to the Governor, Council, and Assembly of the province in recognition of the hierarchical order of governance. For example, Pittman's I699 petition began "To the Right Honble Samuel Allen, Esqr Governor and commander in Chiefe of his Majesty's Province of New Hampshire and Councill Assembled". Similarly, a petition presented by Eleanor Stickney of Hampstead in December of 1755 began "To His Excellency Benning Wentworth Esqr: Governor \& Commander in Chief In \& Over his majesty's Province of New Hampshire[,] the Honble his Majesty's Council[,] and House of Representatives for Said Province in General Assembly Convend". 9 Given the formality of the address, it is possible to assume many petitioners consulted a source, either human or literary, on the proper format before submitting their appeal.

The petitioner followed the salutation with an explanation of the complaint or problem and the resulting difficulty of her position. Women's petitions covered a wide variety of topics. Some petitions

\footnotetext{
6. Petitions, I697, NhAr. NC, 1978), p. I 13 .

8. Lawe of $\mathrm{NH}$, vol. I, p. 147 and vol. 3, p. 493.

9. Petitions, I699, and 1755 , NhAr.
}

7. Crane, Ebb Tide in New England, p. I 50 . Interestingly, Rhode Island seems to have often charged more in government fees. James Kettner found that "[o]nly in Rhode Island were the costs of naturalization consistently high", up to $£_{7}$, while Massachusetts charged just under $8 \mathrm{~s}$ in 173 I. James H. Kettner, The Development of American Citizenship, I608-1870 (Chapel Hill, 
covered local land problems, while some women took part in requests for new towns or a tavern license. Individuals may have requested assistance in dividing an entailed estate, limiting the legal trade in alcohol, or regaining losses from wartime efforts.

Whether the petitioner was male or female, each petition was worded in such a way as to gain as much sympathy as possible. Thus it is easy to interpret the wording in petitions as a plea from the powerless because they are full of phrases meant to arouse sympathy: "being in a low condicion [sic] \& sickly \& weake \& not ablt to manage business as formerly", or "My Necesity Oblidges Mee Once More to Recommend My Miserable Circumstances to the Honorbl Generall Court", or "under the Poor Circumstances in which she is left by the Death of her late Husband". ${ }^{\circ}$ However, the purpose of the petitions, to persuade the government to grant the request, made such phrases so common in petitions as to be formulaic. (Even Thomas Jefferson, in writing the Declaration of Independence, wrote "We have Petitioned for Redress in the most humble terms".) Both men and women used a language of subservience in their petitions to the government. ${ }^{\text {II }}$

While women used terms such as "powerless" and "helpless" far more often than men, the wording men chose, which usually concentrated on their economic weaknesses, conveyed a similar message of need. Therefore, in individual petitions, when women petitioned for their "fatherless children" or to asked the government to aid them due to "Poor Circumstances", the meaning of the wording in their petitions did not vary tremendously from the wording men used, except, of course, that men spoke of their "motherless [rather than fatherless] children". All petitioners mentioned any other possible difficulty in their lives which might create sympathy among the members of the Council and legislature and cause them to grant the request. Language was used to express the understanding of governmental power and authority. But, consciously or unconsciously, language could also be manipulated to achieve a desired end.

Humble phrases also reminded those who wrote them and those who received them of the paternalistic order of society. Free, white, wealthy males dominated the Anglo-American hierarchy. But status included more than gender; it included class, economic status, access to power, family, and certain other intangibles as well. A certain degree of subservience was expected from petitioners, no matter their age, sex, or economic status; and

I0. Petitions, 1693, 1759, and 1745, NhAr.

II. Individual men occasionally appealed to the government by expressing their utter helplessness. Two seamen, Andrew Peterson and Henry Acreman, asked the Governor and Council to "[c]onsider the poor distressed state of your petitioners being altogether helples for want of mony or means or skills"; Petitions, n.d., NhAr. 
whether they felt subservient or not. It was simply part of the process. The ritualistic, humble language incorporated into petitions did not negate the impact the petition and the petitioner could have on governmental actions.

Petitions to the provincial government in New Hampshire were common throughout the eighteenth century. But, despite the fact that petitioning was used by all in society, many historians of women have taken the words in women's petitions literally, as illustrations of inherent female weakness in colonial society. In her I 980 study of women of the American Revolution, Linda Kerber conceives of petitioning as an almost purely political act and one that was not used by women before the I 770 s. Petitions submitted by individuals Kerber dismisses as mere "individual expressions of opinion". To Kerber, the petitioning process is "the most primitive of political mechanisms" which gave women access only to the least controllable and most cumbersome of grievance procedures. She emphasizes the deferential nature of petitions and women's lack of power in the political process. Deborah Rosen, too, finds petitions to have been a much weaker route to justice. Despite what she takes to be the inherent weakness in petitioning, Rosen finds that it was the route more often chosen by women, instead of the courts, a route men followed. ${ }^{\mathrm{I2}}$

But both Kerber and Rosen are snared by the submissive language of petitions and miss the importance of the process and the opportunities petitioning gave to women. Petitioning gave women a voice where they would otherwise be voiceless. Petitions provided the opportunity for far greater female assertiveness and civic involvement than either Kerber or Rosen allow. Petitions may be viewed as powerful tools for the disenfranchised, a group that included more than just women. Petitions were often the most direct means of communication between the provincial government and its subjects. They were the means whereby "individuals could seek the employment of public power to redress private wrongs". Since petitions were most often "individual expressions of opinion", they allowed the voices of any private subject to be heard in a way no other political device could. As Stephen Higginson explains, "petitioning meant that no group in colonial society was entirely without political power", even the married woman under coverture. Gregory Mark notes that "even individual grievances embodied in petitions carried powerful political weight simply because of the individual's capacity to invoke public power". ${ }^{13}$ Women knew it was the duty of their government to hear and respond to petitions presented to them and they turned to their

I 2. Linda K. Kerber, Women of the Republic: Intellect and Ideology in Revolutionary America (Chapel Hill, NC, I980; repr. New York, 1986), pp. 4I, 98, 287; Deborah A. Rosen, Courts and Commerce: Gender, Law, and the Market Economy in Colonial New York (Columbus, OH, I997), pp. II4-II5.

I 3. Higginson, “A Short History,” pp. I44, I53. Mark, “The Vestigial Constitution,” p. 2 I 82. 
government when needed. It was not legislative or executive power they sought, understanding their place in the overall hierarchy of colonial society. They used the legal custom of petitioning as a means to find an efficient remedy to a situation in which the government could provide a solution.

Since petitions were a means by which the disenfranchised could inform, warn, or otherwise instruct the government, they allowed for broad participatory action at a time when the Assembly as well as the Governor and Council accepted all petitions placed before them. ${ }^{14}$ Colonists used the mechanism of petition for a tremendous variety of purposes and the process was open to women as well as men, whether married, single, or widowed, rich, middling, or poor. The fact that most petitions were submitted by individuals, or very small groups of people, did not diminish their importance. Petitioning was a legal custom accepted throughout the colonies.

In New Hampshire, the procedure for dealing with petitions was straightforward. Petitions apparently received two main hearings: one before the Governor sitting with his Council and a second before the Assembly, often on the same day. The notice of action taken on each petition was supposed to be written in the margins or on the reverse of the petition, but unfortunately the casual nature of $\mathrm{New}$ Hampshire provincial governance meant that often the clerk neglected his duty. For many petitions no indication exists of approval or disapproval on the petition. But it is possible to discern the unwritten decisions for many petitions through the minutes of the Council or Assembly or through the disbursement lists from the records of the Treasury.

The petitions presented by women to the New Hampshire government tended to be from women who were either widowed or without a male presence in their households, for one reason or another. Of the I 53 women whose signatures are clear and who filed petitions between I695 and 1770 which are still extant, 20 women joined mass petitions to request new townships. But most women ( 87 per cent) submitted petitions aimed at rectifying individual concerns. Along with five women whose petitions do not fit into any particular category, a handful of women, four, informed the government of abuse they suffered at the hands of their husbands and three others requested a divorce. Seven women disagreed with judicial decisions and wanted the government to order the courts to rehear a case;

I4. Although he concentrates on petitions submitted with large numbers of signatures, Edmund S. Morgan has written that petitions "nourished the fiction of the people's capacity to speak for themselves. In doing so they renewed the invitation that popular sovereignty unavoidably extended to flesh-and-blood people outside parliament who thought themselves qualified to do the speaking", an interesting thought, particularly when applied to women; Edmund S. Morgan, Inventing the People: The Rise of Popular Sovereignty in England and America (New York, I988), p. 230. 
six wanted financial help because they had been captured by Native Americans. Ten women submitted petitions relating to their work as tavern keepers or their desire to keep a tavern. But the largest number of cases may be placed in two categories: 43 women $(28$ per cent) entered petitions dealing with real or personal property issues, and 55 women $(36$ per cent) submitted war-related petitions. ${ }^{\text {Is }}$

Statistics give important information, but the stories behind the stark facts make petitions an unusually good source of information for social historians. Looking at the divorce petitions, for example, is revealing. Divorce, it is generally agreed, was easier to receive in New England than in England. But not in New Hampshire. As one petition put it, "there is no Executive court in this Province [that] has jurisdiction of such a Cause". In New Hampshire, divorce was allowed only by special act of the legislature and special acts began with a petition. Between I695 and I770, just three women filed a petition for divorce. The most common problem cited as a reason for divorce was adultery. Eliza Smart's petition for divorce in I697 indicated a clear need and desire on the part of both parties to end their marriage. Smart "presented her petition desiring a divorce from her husband, he being married to another woman at New York as by testimony from his own hand to Jno. Hinks, Esq. President, as also the testimony of Rob. Almary". Similarly, Eleanor Stickney faced her husband's adultery after a twenty-year marriage. In 1755, Stickney explained to the Governor, Council, and Assembly that her husband had "kept Company with One Mehetable Guile a Single Woman [...] \& had Criminal Conversation with her". Then the two lovers had fled to Springfield, Massachusetts "where they lived together as Man \& Wife". A shamed Mehetable returned to her home town and confessed to their sins while James fled. ${ }^{16}$

Interestingly, none of the divorce claims use abuse or economic neglect as a reason for divorce. Many women who were, or believed themselves to be, abused or neglected, and who had friends or family willing to house them, simply absented themselves from their hearths and husbands. But, very occasionally, they also alerted the government to their treatment. Ann Foss, wife of the innkeeper Zachariah, informed the government that her

I5. New Hampshire petitions may be found at the Division of New Hampshire Records Management and Archives in Concord, NH and in New Hampshire, Provincial and State Papers, 40 vols (Concord, NH, 1887-1943) [hereafter NHPP]. The archivist for the state is in the process of matching both published and unpublished and unindexed committee reports to petitions.

16. NHPP, vol. 2, p. 249 (Smart); Petitions, 1755, NhAr (Stickney). The other divorce may be found in Petitions, 1765 and $1766, \mathrm{NhAr}$ (Barrell). A similarly small numbers of male petitioners requested a divorce. In one very interesting case, Greenwood Carpenter was granted a divorce from his wife, Sarah Leathers Carpenter, in $177 \mathrm{I}$ by the New Hampshire government. Two full years later, the divorce was rescinded by the royal government in England; NHPP, vol. 7, pp. 22, 272. 
husband "has by a long Course of illusage and Unkind treatment to her [...] Obliged her for the preservation of her health \& Safety to leave him \& throw herself on the mercy of any Acquaintance \& friend for present Support". She feared his "unsteadiness of Temper, and Ungovern'd Passions" and asked the government, not for a divorce, but for protection for herself and her friends. Zachariah replied with an acerbic petition of his own and battle was joined, one that dragged on to no discernable conclusion.

In a case of perceived economic neglect, the widow Mary Macris and her children had lived comfortably on the profits from land inherited from her father and a deceased husband. But then she married Joseph Macris "justly Expecting that he would help me in my difficulties" of widowhood. When she discovered, apparently to her surprise, that her second husband would not allow her to control the income-producing investments she brought into the marriage nor give her the disposable income she controlled before her remarriage, she left him. After living on her own for three years, she petitioned for the right to

[...] take the said Estate into her own hands, to apply the profits thereof to her own \& Infant Children's support, to maintain an Action in the King's Court in her own Name, for the Recovery of the Debts due her while she was Sole, and for any other matter or thing properly belonging to her, \& to Dispose thereof as she might do by Law, if not under Coverture.

Macris must have realized that she was treading on thin ice: the government could not condone the actions of a woman who had left her husband. Macris hoped for the opportunity to act as a feme sole, an unmarried adult woman. She was disappointed: her petition was dismissed.

In her bid to act as an independent agent, shopkeeper Elizabeth Pascall was more successful. Around 1753, Pascall's husband, Michael Henry, was in some way detained in royal service. In 1763 , after supporting herself for the previous ten years, Pascall petitioned the government to sell land she had inherited and, further, for the right to act as a feme sole. "Michael Henry Pascall Esq hath been absent from your Petitioner Beyond seas for more than ten years Past \& still is Detaind in his majesties Service and it is uncertain when he will return.” Pascall reasoned, since she had supported herself without her husband's aid in his long absence, she wanted

[...] to make sale of her said Land, the whole or any Part, or to dispose of the Same by will \& also that she may be enabled to Contract in her own name \& to Sue or Defend any action in law as if she were Sole notwithstanding her aforesaid Coverture.

In this instance, the right was granted; however, Pascall's life did not change dramatically. She was able to sell the land, as she requested in her petition. With feme sole trader status, she could, with more surety, make 
contracts with shippers, purchase goods from English suppliers, and provide what her customers wanted, all in her own name. Pascall was the only woman, or the only one for whom records survive, to receive feme sole trader status in New Hampshire during the entire period under study and her circumstances were unusual. The ten-year absence of her husband had turned her into a virtual widow without the benefit of dower. ${ }^{17}$

Although women did have the opportunity to use petitions to explain to the government problems within their marriage that they felt warranted attention, most women did not petition for actions which interfered with the duties and legal rights of a husband. Not only were such petitions seldom successful, but women seldom submitted them. Such petitions passed the outer limits of women's acceptable roles. Women's petitions were far more frequent, and more successful, where they requested action that would aid the entire family. Women's accepted role as mistresses of their households, mothers of their children, and consorts of their husbands gave them the power to fight for their families. ${ }^{18}$ When women, either as widows or within the understood boundaries of wives, presented cases in which their chief aim was clearly to improve or protect the condition of their families, especially their children, their petitions were well received, well considered, and generally granted.

One of the two largest categories of petitions submitted by women involved property issues. Widows often needed some assistance with the estates of their recently deceased husbands. In 1769 Hannah Jose petitioned as administratrix of her husband's estate for the right to sell some land to pay his debts. Ann Clark asked for the right to cut the entail on her husband's estate and to sell the land in parts. Her adult children were with her when the petition was presented and agreed to the request. When Leah Nutter's husband's estate was divided without regard to his will, Nutter petitioned the government for assistance she was not getting from the probate judge. In I 768 Mary Marston requested the right to have the judge of probate "to Cause Partition \& Division of their said Estate to be made in the Same manner [...] as he may by Law do of the Real Estates of Persons dying Intestate". ${ }^{19}$ Most requests by widows to ease the sale of land, redistribute an estate, or settle a problem of inheritance were granted.

17. Petitions, I74I, I743, and I767, NhAr; NHPP, vol. 5, p. 695; vol. 7, p. I 48 (Foss and Macris); Petitions, 1763 (Pascall), NhAr; Raymond A. Brighton, They Came to Fish: A Brief Look at Portsmouth's 350 Years of History; It's Local and World-wide Involvement and the People Concerned Through the Eyes of a Reporter (Portsmouth, NH, 1973), p. 45; The New-Hampshire Gazette, 2 March I764, p. 3, and 6 March I761, p. 3; NHPP, vol. 6, pp. 866, 885; NHPP, vol. 7, p. 44 (Pascall).

I8. Ulrich, Goodwives. Ulrich concentrates on the many different roles colonial women played in Anglo-American society.

I9. NHPP, vol. 3, p. 380 (Jose); ibid., vol. 4, pp. 42-43 (Clark); Petitions, I748 (Nutter), I768 (Marston), NhAr. 
The requests would benefit the family and generally ease the families' transition from one generation to the next while posing no threat to the existing social order.

New widows were not the only ones trying to deal with land issues on the turbulent northern frontier. As times of war repeatedly emptied the land of white settlers while periods of peace pushed the line of white settlement farther west and north, women were forced to fight for their land. The initial illustration in this article is just such a case. Deliverance Derry Pittman requested the return of land taken by the men appointed to settle her first husband's estate. Their legally-appointed control left Pittman without remedy - except through petition. In another land issue, a woman with grown sons petitioned the government with her daughterin-law to reclaim land lost in the French and Indian War. Judy and Margaret Moore were captured from what is now the Brattleboro, Vermont, area in 1758. In her petition to the New Hampshire Governor and Council, Mother Moore explained, "Your Excleneys Humble Petisoners [...] have under gon a great deall of hardships By the war[...] $[\mathrm{F}]$ or in the year 1758 my husband and on[e] of my Sons was Kiled upon the spot". Along with the dead son's wife and children, she was captured but redeemed. Moore petitioned the government for her daughter-in-law and her "three men grown" sons in order to regain title to land the family had worked for the past twelve years. The petition was signed first by the two women and then by the three adult sons, followed by witnesses. ${ }^{20}$ Clearly the children, even the adult men, bowed to Mistress Moore's desire to save the land for the family. No other word but respect for the family matriarch seems to fit their actions. As a matriarch, the family turned to her to act as the family agent to provide the leadership, stability, and continuity that the children, despite adulthood, needed.

As in the Moore example, women's role as head of the family was most apparent during wartime and the largest number of petitions were submitted by women affected by war. To date, histories of the preRevolutionary colonial wars have focused on the men who fought. Whenever there was any mention of the women the fighting men left behind, it focused on their plight, not the options available to them. This is natural enough, since many women did confront immense difficulties in the loss of their spouses. Mental, physical and, most urgently, monetary challenges faced women during war as they grappled, some more successfully than others, with the work of two. Women took on the work of their departed husbands with the expectation that their extra burdens would end with the return of their husbands and the conclusion of the war.

20. Petitions, 1699 (Pittman) and 1760 (Moore), NhAr. Margaret and Judy Moore were motherin-law and daughter-in-law and the main part of the petition refers to the mother-in-law. It is unclear, however, which was which. 
But, in northern New England, warfare was almost constant during the last roo years of colonization. The imperial wars between France and England: King William's War (I689-I697), Queen Anne's War (I702I7I 3), King George's War (I744-I748), and finally, the French and Indian, or Seven Years War (1754-I763), were punctuated with several periods of intensified Anglo-Native conflicts in northern New England. In his history of New Hampshire, Jeremy Belknap noted that by 1725 "every man of forty years of age [had] [...] seen more than twenty years of war". ${ }^{21}$ The wartime service of fathers, husbands, and sons was a normal part of life for every generation of colonial women.

As the agents of their families, and in their husbands' absence, wives were able to act with the authority that their husbands generally had, guiding their families. They were responsible for the immediate wellbeing of their families. Colonial governments turned to the wives of men who were absent in order to provide stability for individual families and thus order for the entire society. The best example of this is during King George's War (I744-I748), when New Hampshire and Massachusetts leaders decided on a bold plan to use colonial militia to attack the seemingly impregnable French fortress of Louisbourg. Fortress Louisbourg guarded the entrance to the St Lawrence River, the gateway to Canada, from a peninsula in Nova Scotia. New Hampshire and Massachusetts contributed the bulk of the soldiers for the successful colonial attack. $^{22}$ To encourage men to enlist in the Louisbourg expedition of I745-1746, New Hampshire legislation included provisions for widows. "The Widows or nearest relatives of any officer or soldier that is slain or shall otherwise loose [sic] his life in the service, shall be entitled to four months pay." But the legislation also included a further provision to protect the wives left behind. "[T] he wives of any officer or soldier in the Expedition or any other person that appears with a power of Attorney duly authenticated, shall at the end of every month receive out of the Treasury half or all the wages of such officer or soldier as he appears for." The government used the pronoun "he" when referring to those with power to request wages, but the passage started with "wives". Thus encouraged, wives of men in the New Hampshire regiment of

2 I. Jeremy Belknap, The History of New-Hampshire, vol. I (Dover, NH, I 8 I 2 ; repr. New York, I970), p. 217.

22. George C. Gilmore, compiler, Role of New Hampshire Soldiers at the Battle of Bennington, August 16, 1777 with [the] Roll of New Hampshire Men at Louisbourge, Cape Breton, I745 (Manchester, NH, I89i and Concord, NH, I896; repr. Baltimore, MD, i995), pp. I5-i6, estimated that New Hampshire sent 500 men. William Douglass's pamphlet claimed New Hampshire "contributed of 350 Men under Col. Moor", and later sent 200 reinforcements for a total of 550 soldiers; Douglass, A Summary, p. 48. Peckham's study reports that New Hampshire contributed 450 soldiers; Howard H. Peckham, The Colonial Wars, $1689-1762$ (Chicago, IL, i964), p. 100. 
approximately $500 \mathrm{knew}$ they had the right to petition the government for at least part of the pay of their men - should the need arise. None of the existing petitions that requested payment of the wages of a living relative include a "power of Attorney duly authenticated", so perhaps the reality of wartime need ultimately superseded legal exactions in the eyes of those who wrote and heard petitions. During the later French and Indian War, the New Hampshire legislature ordered "that the Ballance for wages due to each person as carried off against his name be paid to him, his order, widow or Legal Representative". The legal representative was almost always a soldier's wife or widowed mother. ${ }^{23}$ The legislatures of northern New England recognized hierarchy within the family as well as the need for wives/widows to act with an understanding of the "mutual responsibilities" of the marriage partnership. Actions taken by the "war widows" of New Hampshire were well within the bounds of traditional female roles; in this case the role as the family's representative or agent. It is also important to note that members of the colonial paternalistic society expected wives to take on this role. No petition from a woman relating to war issues, or any other matter, was dismissed simply because it was from a woman.

The petitions relating to war may be divided into two main subcategories: petitions requesting an allowance from the husband's earnings, and petitions requiring reimbursement for goods lost in battle or on an expedition. The petitions for allowance emphasized subservience and need and fit the "helpless widow" or at least "helpless female" stereotype. "Sundry Women whose Husbands are gone in the Expedition against Louisburg" petitioned the government in June 1745 for an allowance from the wages their husbands had thus far earned as soldiers. "Your Petitioners families are in Daily Want of Support \& are now destitute of the help they used to have by the Day Wages of their Husbands on which only they Depended for Subsistence." The fifteen women who signed the petition stressed the perilous position of their households and their dependent nature as wives. They depended on their husbands' ability to bring in income and to ease the burdens of family life. Without their husband's presence and work, their already heavy workloads were greatly increased.

However, upon closer inspection, the petition may be seen as more than a plea from the powerless. It was a message from women who, while poor and overburdened, knew that the government owed them money and knew how to inform the government of its obligations. And it was more than that: it was the second petition from the fifteen signers. The money granted in the first "being but Small was Soon Expended". They petitioned once again, arguing that "it Seems unreasonable that the Families of those

23. Laws of $N H$, vol. I, pp. 374, 473-474; NHPP, vol. 6, p. 880. 
who Expose their Lives daily for the Good of their Country should be left to Suffer". ${ }^{24}$ Their households, which had depended upon the "Day Wages" of their husbands, now depended upon the willingness of the wives and mothers to use their right of petitioning to attain needed cash for their families. The government owed the soldiers' families the money and had provided the means for the women to collect. Although no record remains as to the outcome of their second petition, the fifteen "sundry women" willingly approached the seats of power to maintain themselves and their families, fully understanding that since their husbands had earned the money and it was owed to the soldiers' families, there was no reason to fall upon the pocketbooks of their neighbors for charity. ${ }^{25}$ Further, as the wives of day laborers, it is also clear that even women of little means understood and willingly used the petitioning process. Usually, twentiethcentury historians view women of lower status as virtually powerless. Powerful they were not, but neither were they voiceless. Petitioning was the most efficient way lower-class women could expect their individual needs and the needs of their families to be heard.

Other women, finding themselves in similar circumstances during their husbands' absences, approached the government with similar aims. As a result of the Louisbourg expedition, in April I747 Ann Brotton, Sarah Tucker, and Sarah Messuere informed the New Hampshire provincial government that "your Petitioners were very nearly affected by and Concerned in the Loss of those Men lately belonging to the Sloop Warren [...] One having a Son \& the other two their Husbands among the Captives". Along with the anguish they must have felt in fearing the worst for their loved ones, they also felt the need to protect the wages of their men. The only way to do that was to bring the situation to the attention of the government and state their expectations. Their men "had been a Considerable time in the Service before they were taken [by the French] for which the Wages Ramins due". Further, "it Seems to your Petitioners but just \& Equal that their Wages Should be Continued till their Return Or if they are dead till there shall be Certain News thereof". Therefore, the women requested all the wages owed "to this time" be paid to them, and that the men be allowed to continue to earn wages until news of their condition was discovered. After stating their case in the most straightforward manner possible, they then added a seemingly perfunctory "Or that you would Grant them Such Relief under their Afflictive Circumstances as in your Great Wisdom \& Goodness you See Meet \& your petitioners as in Duty bound shall Ever Pray \&c". Having couched their words in an acceptable formula, the supplicants felt free not only to ask for the wages

24. NHPP, vol. 17, p. $225-226$. The first petition is no longer extant.

25. In New England, individuals who needed assistance could also turn to their towns for support. However, they then became a public charge. Most people preferred to collect money owed them rather than use town welfare. 
owed to their men, but also to explain to the government how wages should be paid and for what length of time. After all, the "Petitioners Families [...] depended on their Respective Relatives [...] for their Subsistence and their Wages in the Service was the only Means of the Support of themselves \& families". Their predicament was "Occasion'd by their [men] Entering into the Public Service" when the mother country needed sailors. If the needy families did not receive aid, then the women would have to proceed as best they could until their husbands returned or were declared to be dead. ${ }^{26}$ Either way, the continuance of the families of the three supplicants was up to them. They were doing the best they could with the means available to maintain their families.

Similarly, the only time Elizabeth Ham of Portsmouth approached the provincial government was to petition for her husband's wages. However, she was a recent widow, not the wife of a living soldier. On ig February I746, a petition was entered "per her order", explaining that "Your Petitioner has a family of small Children to maintain \& no Estate whereon to Depend they having been hither to Supported by the Industry of their Parents". Through the use of the plural, Ham left no doubt that she provided half of the support for her children through her "Industry". With the other half of that industrious partnership dead at Louisbourg, Ham petitioned the government, asking for, and receiving, the rest of her husband's wages from the soldiers' pay in the Treasury. ${ }^{27}$ She entered her request with the aim of self-support. She did not want to become a public charge. Like women in similar circumstances, need drove her actions, but means, and at least a temporary remedy, were available.

Sarah French, a recent widow from Hampton, New Hampshire, used a slightly more aggressive tone in requesting a nonwage allowance from the government. In a patriotic move before leaving for the Louisbourg expedition, French's husband apparently mortgaged all the property they owned "for Security for the Payment of twenty five Pounds of the Loan money which he took up". He had invested not only his life but all that he owned in the expedition, as the "loan" money of which she wrote was money raised by the province to cover wartime expenses. But in doing so he left his "Large family of Small Children" and widow in dire circumstances. "Your Petitioner Can see no method by which She Can Possibly Pay the Interest or Clear the Mortgage unless your Excellency and Honours in Your Great Clemency Shall be Pleas'd to make me some Considerations herein for my Relief." The request here is clear: French was hoping that she "could be Reliev'd herein [of the interest payments]

26. Petitions, 1747, NhAr. Also in NHPP, vol. I8, pp. 305-306. The italicized word was underlined in the original petition. No notice of action on this petition exists.

27. Like many petitions, Ham's petition and mention of it are found in many parts of the records. The quote is from Petitions, 1746 , NhAr, but notice of the petition may be found in NHPP, vol. 18, p. 264 and ibid., vol. 5, pp. 406, 795 . 
for the present that hereafter by Industry and the Blessings of God I Should be able so to Clear the Said Obligations". Without some temporary release from the mortgage interest payments she must "be Strip'd Bare of every thing and turn'd Out of Doors with a Large family of Small Children to the mercies of the world". ${ }^{28}$ The implied questions reverberated loudly: did the government want to create another public charge? Had she not paid enough already? She was not planning to renege on her responsibilities: eventually she would pay what her family owed. She appealed to the government to allow her the chance to continue to support her family and delay payment of the debt. The burdens of death had forever altered French's part in the world. Like all widows, her life now depended on her ability to provide the resources for her family's existence.

Requests for aid or a wage allowance had a tone that differed from petitions for reimbursement. Women who asked for reimbursement were more direct and less guarded in their petitions. When Mary Moore, wife of the New Hampshire regiment's commander Colonel Samuel Moore, felt that her husband had overextended their family's finances in the cause of empire, she presented a petition to the colony's government on 27 September 1745. Colonel Moore, she explained, "hath advanced consid-

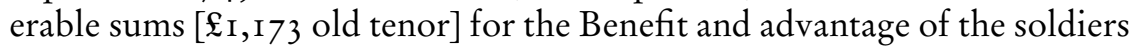
at Louisbourg under his Command", and she asked that the government "give your Petitioner opportunity to produce the vouchers for the Sums advanced", as well as an accounting of what was "due to him the said Samuel for him self and servants", so that the government could repay the sum owed to Colonel Moore "[u]nto your petitioner". ${ }^{29}$ While no known personal correspondence exists which can confirm the request from husband to wife, the detail given in the petition leads to the logical assumption that Samuel had written to his wife explaining his expenditures and expectations of repayment. Another logical explanation is that Mary kept the accounts herself. Mary Moore was the person her husband chose to act in his stead, and she acted knowing that as a subject she had the right to petition the government and to be heard.

The petitions from women requesting reimbursement for nursing were as straightforward as Moore's petition. Illness attacked almost every expedition of soldiers away from home for any length of time. Thus many of the soldiers who returned home arrived sick and needed nursing. In several petitions throughout the eighteenth century, women requested payment promised by the government for the nursing of soldiers. For instance, in 1763 Susanna Parker of Charlestown appealed to the government in a well-documented petition regarding her care of a sick soldier who was "helpless as an infant" for much of the time. The distance 
from Charlestown on the Connecticut River to the seat of government in Portsmouth on the Atlantic seacoast meant Parker did not appear personally, and her case had to be as strong as possible if there was any hope of success. In an itemized account, she charged $£_{22}$ I I d for candles, wood, bed, bedding, and board of the soldiers. Finally, she included a petition from William Hanson, the father of one of the sick soldiers, supporting her claims and verifying that Parker cared for his son for seven months. It was Hanson, a lieutenant in the New Hampshire militia, who presented the petition to the Governor, Council, and Assembly. Parker included a note from the Charlestown Justice of the Peace. "[T]here appeared Susannah Parker Subscriber to the above Accompt and made Solemn oath that the same was Just [and] True." Similar petitions regarding the nursing of nonrelated soldiers were not unusual. For instance, Hannah Osgood of Concord who was paid for nursing soldier Samuel Houston for forty-one days in her tavern in 1754 while he began to mend from a broken leg; and the Widow McClanen of Brentwood who was paid over $£_{100}$ in I76I for nursing James Moody, who returned from his stint in the militia with smallpox..$^{30}$

Some women considered the nursing of their returned ill or injured family members warwork worthy of compensation by the government. Elizabeth and Mary Drown, wife and daughter respectively, presented a bill to the New Hampshire provincial government for nursing Samuel Drown, who had been wounded while scouting in the Rochester area in May I748. Their petition was sent to the government along with Samuel's separate petition for aid. Samuel explained to the representatives that he was "now Extrem Ill at portsmo[uth] \& being under Low Sircumstances Borth [both] of Body \& purse \& being wounded in the province Service Beg you would make Some provision for me to prevent my Soffering \& for my Comfortable Sorport”. His wife and daughter were less circumspect in their approach to the government. "The Province of New Hampshire Debtor to Elizabeth Drown for nursing the said Drown in the year 1747 when he was wounded by the Enemy and Car[ri]ed Down to Portsmouth [...] we expect the Common wages that is allowed for nursing." Elizabeth had nursed her husband for ten weeks and Mary had attended her father for eight. The petitions had the desired effect because the government agreed to support its wounded scout "in the most frugal manner" and to pay his family the customary allowance for their nursing services. ${ }^{3 \mathrm{I}}$

A petition from the French and Indian War attracts more attention (and

30. Petitions, 1763 , NhAr; Donna-Belle Garvin and James L. Garvin, On the Road North of Boston: New Hampshire Taverns and Turnpikes, 1700-1900 (Concord, NH, 1988) p. I38; Petitions, I76I, NhAr.

31. Petitions, I748, NhAr, and NHPP, vol. I 8, pp. 307-308. The government "voted that Elizth Drown be allow'd \& pd twenty shills \& Mary Drown ten shills in full of their accts for Nursing of Saml Drown"; NHPP, vol. 5, p. 579. 
pity) from the twenty-first-century researcher. In 1762 , the widow Bridget Clifford of Brentwood petitioned for "money to get her sick soldier son home from Albany". We can imagine her distress, knowing her son was too ill to return home himself where she could look after him. Then she added a line to her petition that shed light on the difficulties the war had caused her: "I Lost two Sons that went in the Expedition that way already". ${ }^{22}$ She was eager to nurse her sole surviving son to health if the province would just bring him home. The only means she had available to let the government know of her willingness, desire, and ability to do so was to petition.

As the weeks stretched into months and their men did not return, women who were related to injured, lost, or killed combatants learned that the temporary burdens they shouldered could become permanent ones. Death was no stranger to soldiers away from home - or their wives. Petitions from women who had suffered the deaths of their spouses had the greatest air of urgency. Usually unknown in public records before the deaths of their spouses, widows, now femes sole, became the public speakers and, if without an adult son, the sole representatives of their households. In order to succeed in their petitions they had to rely on memory, the testimony of friends and comrades, and itemized accounts. Deborah Dunn of Portsmouth entered the official government records when she petitioned the government in 1746 . Her husband, a carpenter named Nicholas, had volunteered for the 1745 Louisbourg attack and there had died in battle. She used the usual words to explain her helplessness: "Your Petitioner is a poor helpless widow \& Nothing but her hands to get [...] her living”. But after that she placed formulaic helplessness aside in this, her only appeal to the provincial government. Dunn enclosed a detailed list all the items lost by her late husband, "one of the Bold Adventurers in the Attack of the Island Battery", that included a gun, a knapsack, a cartridge box, a hatchet, five pairs of hose, three pairs of breeches, three jackets, one coat, one shirt, one pair of silver buckles (worth $£_{3}$ ios alone), and a hat. The total value of all the goods came to $£_{37} 4$ s old tenor. The government apparently agreed with her accounting and allowed her a generous $\mathfrak{E}_{\mathrm{I}} \mathrm{S}$ new tenor within a week after hearing her petition. ${ }^{33}$

32. Petitions, I762, NhAr. Although no known action was taken by the governor, council, or legislature, the request to transport sick soldiers once they were well enough to move was well within the norm.

33. Petitions, I 746, NhAr and NHPP, vol. I 8, pp. $283-284$, 287, and $i b i d$., vol. 5, p. 45 I. In 1742 New Hampshire revalued its currency and created new tenor currency with a four to one exchange rate with old tenor, an exchange rate which continued to rise. Yet for some reason, in most petitions in which specific debts were enumerated, the petitioners continued to use old tenor in their accounts throughout the colonial period. Thus the $\mathfrak{I}_{I} 5$ new tenor that Dunn received was very generous and/or may have included other debts owed to Dunn by the government. 
When Olive Russell of Litchfield petitioned the New Hampshire government in 1758 , she included an itemized list and a sworn statement signed by Justice of Peace Matthew Patten. Lieutenant Pelatiah Russell left home in 1757 with

[...] [a] good new Beaver hatt, two new worsted Caps and one woolen shirt, three good Jackets and one Coat and two Pairs of Leather Breeches, three Pair of Stockings and one Pair of Shoes and one Pair of Magezens [moccasins], one Silk handkerCheif and one Cotton hander Chief and a Gun and Snapsack [knapsack?] and Powder horn.

Either Widow Russell had an extraordinary memory or she and her husband had written it all down just in case Olive needed to produce such a list. The sworn list worked. The legislature approved payment of $£_{I} \circ 0$ for the missing articles and three months wages. ${ }^{34}$ It was Russell's first and last known official contact with the provincial government. Despite her lack of any other communication with the general government, she knew and understood the power of petition and used it when she needed to.

Elizabeth Goudy of Portsmouth tried a similar approach when she became a widow upon the death of her husband, James, who was also killed while serving at Louisbourg. She delivered a petition to the government explaining that her husband had been "charg'd by Capt Mason with two Guns one of which he return'd to Capt Mason \& the other into ye Province Store for the Expedition against Canada”. She received sos new tenor for the mistaken reduction of her husband's final wages. Goudy did not stop with her attempt to seek redress for gun money. She also sent an itemized list of goods that her husband had taken with him to Cape Breton but "that I never received", including a shirt, hat, shoes, "the lace about the Hat," a pair of stockings, "waring Cloathes", and a chest - for a grand total of $£_{20}$ I 8 s old tenor. 35 But, interestingly and sadly, this was not the last time Elizabeth Goudy came before the government. In 1760 , during the French and Indian War, her son Hugh was killed. Perhaps because her petition during the previous war had been well received by the provincial government, Goudy sent an itemized list once again this time asking for $£ 83$ Ios old tenor for "Sundry Articles her Son lost when in the Army in the year 1760". Once again the government honored her request and paid her what was by then the equivalent amount in new tenor: $\mathfrak{E}_{\mathrm{I}} \mathrm{S}$. On the eve of the American Revolution, she again petitioned the government, explaining that her husband and son had been killed in the service of the province and asked for her son's remaining unpaid wages of $£ 85$ s. Then she added to her 1774 petition a request "that

34. Treasury Records, 1758 , Box 8 , NhAr.

35. The petition may be found in NHPP, vol. 5, p. 457 and the itemized list in Treasury Records, Miscellaneous Treasury Account, NhAr. 
your Excellency and Honors would be pleasd to consider whether your Petitioner is not equitably entitled to some allowance from the Government for the time her husband spent in said Expedition before his Death, for which neither he or She ever received any Consideration". ${ }^{36}$ Tenacity in the face of grief paid off for this strong northern New England woman.

Like the petitions of war widows to the colonial New Hampshire government, petitions from women were requests that required special governmental action. Not every woman with a case exercised her option to petition, nor did every man. But the individuals who did knew petitioning could produce the results they desired. They were informants and, as such, petitioners were the government's most direct contact with the needs and expectations of the populace. As members of society, as subjects of the British colonies, women, as well as men, took advantage of their opportunity to inform their government. At the same time, they respected the distance social position placed between ordinary citizens and the governing elite. Lacking the status to have their needs and expectations met without the necessity of a petition, petitioning gave individuals without any other direct contact with the government a legal mechanism to urge the government to fulfill its obligations.

Those who made the effort to petition did so knowing the government would give due consideration to their petitions. Women understood their qualifications as petitioners and their rights before the government. Using societal assumptions of dependence and helplessness in their communications with the government, women were able to use the traditional language of petitioning to put forward their individual needs and demands, all within the acceptable bounds of patriarchy. Many female petitioners had lost their normal family spokesman but remained to face the world for their household, no matter what extra work it entailed. After all, if they did not do it, who would? They knew their families' needs could be addressed, not through the vagaries of the court system, but through the right of petition. The petitioning process gave ordinary women direct access to the highest levels of provincial government and the power of a traditional form of governmental address to rectify a wrong. It was a customary political device that the limitations inherent in coverture and patriarchy did not deny to women. 